\title{
AN EXPLANATION OF THE NON-PRODUCTION OF FERTILIZED EGGS BY ADULT MALE-PRO- DUCING FEMALES IN A SPECIES OF ASPLANCHNA.
}

\section{D. WHitney.}

It has been observed by various investigators in the study of certain of the rotifers that in order for a male-producing parthenogenetic female to develop fertilized eggs the female must pair with the male soon after leaving the egg while she is quite young and small. No one has observed the real reason or necessity for this early pairing.

While working with a species of Asplanchna in the summer of I 908 at Cold Spring Harbor, New York, and again in the present summer it has been possible to watch the pairing of the two sexes under the microscope. This species is one that has very large individuals, probably as large as any species of rotifer. Both the female and the male are very transparent, thus making it possible to observe all the internal organs, including the ovaries and the eggs of the female, and the organs of the male with the living sperm in the testis. The sperm are very large and can be easily seen with the one third objective. When the male and female pair the two individuals come into contact with each other and the male keeping the head pressed against the body of the female bends the body and assuming the shape of a letter $U$ brings the posterior end into contact also with the body of the female. Then the copulatory organ of the male is forced through the cuticle of the female into the body cavity, like a hypodermic needle, and the sperm passing through it are ejected into the body cavity of the female. The sperm immediately become active and, on account of their large size, can be easily observed swimming around in the body cavity of the female. This hypodermic injection of sperm may be made on any part of the trunk region of the female. 
Many observations were made in the pairing of different young females with males. All young females observed were seen to be injected with active sperm from the male. Each female was then placed in a separate watch-glass and allowed to mature and to produce eggs or viviparous young. Some of these young females which were seen to receive living sperm into their body cavities developed parthenogenetic young daughter females ana others developed fertilized thick-shelled resting eggs. It has been shown by Maupas, ${ }^{1}$ Lauterbaum, ${ }^{2}$ Whitney, ${ }^{3}$ and Shull ${ }^{4}$ that if the young male-producing female pairs with a male thick-shelled fertilized eggs will be produced, but it has never been demonstrated that in pairing the female-producing females also receive sperm into their body cavities in the same manner as do the maleproducing females.

Larger and more mature parthenogenetic female-producing females as well as larger and more mature male-producing females were placed with males and many observations made. The male and female individuals come into contact with each other and the male assumes the same position as with the young females. The male makes several attempts to pierce the cuticle of the female with the piercing copulatory organ but is unsuccessful and in some instances sheds the sperm out into the water on the outside of the body of the female. These sperm are active for a few seconds, but soon become inactive and, owing probably to the injurious effects of the water, soon die. This failure of the male to inject sperm into the body cavity of both the adult female-producing female and the adult male-producing female was observed many times and in every case it was a failure. In some instances the sperm were not shed into the water by the male. This seemed to depend more or less upon the condition of the male. If it had been isolated alone for several hours and was young it would shed the sperm out into the water when in contact with the female but if it was old and partly spent it would not shed the sperm out into the water.

1 Maupas, M., C. R. Acad. Sci. Paris, T. CXI., I89o.

${ }^{2}$ Lauterborn, Biol. Centralb., XVIII., I898.

${ }^{3}$ Whitney, D. D., Jour. Exper. Zoöl., V., I907.

4 Shull, A. F., Journ. Exper. Zoöl., VIII., I9Io. 
This ability of the male to pierce through the cuticle of young females and the failure to pierce through the cuticle of adult females is due, probably, to the increased thickness or compactness, or both, of the cuticle of the older females. As the females grow and become older their cuticle, which is supposedly of more or less chitinous material, becomes more difficult to penetrate. It is highly probable that if the sperm could be injected into the body cavity of the adult male-producing females that the eggs would be fertilized and thick-shelled resting eggs would be produced.

Males do not seem to be able to discriminate either between each other or young females of either kind or mature females. They attempt to pair with any other individual with which they come into contact. Males have been seen to inject sperm into the body cavities of each other. Many males from a general mixed culture often contain a few free sperm actively swimming around in their body cavities. These sperm have been placed in their body cavities by other males. Thus it happens that more or less of the sperm of a male may be wasted by being injected into either young female-producing females or into other males, or even shed out into the water in attempted impossible copulation with adult females.

\section{Summary.}

I. Both kinds of young females, female-producing and maleproducing, pair with male individuals and receive active sperm into their body cavities.

2. The young female-producing females having been injected with living sperm by the male mature and produce parthenogenetic daughter-females but the young male-producing females having been injected with living sperm by the male mature and produce thick-shelled fertilized eggs.

3. Male individuals pair and inject active sperm into the body cavities of each other.

4. The mature female-producing females and the mature male-producing females pair with male individuals but do not receive sperm into their body cavities because the copulatory 
EGG PRODUCTION BY ADULT MALE-PRODUCING FEMALES. 32 I

organ of the male is unable to pierce through the thickened cuticle of the adult female.

5. Much of the sperm of the males may be wasted by being injected into young female-producing females or into other male individuals or by being shed into the water in attempted copulation with adult females.

Biological Laboratory, Wesleyan University, Middletown, Conn., August I2, I9I3. 


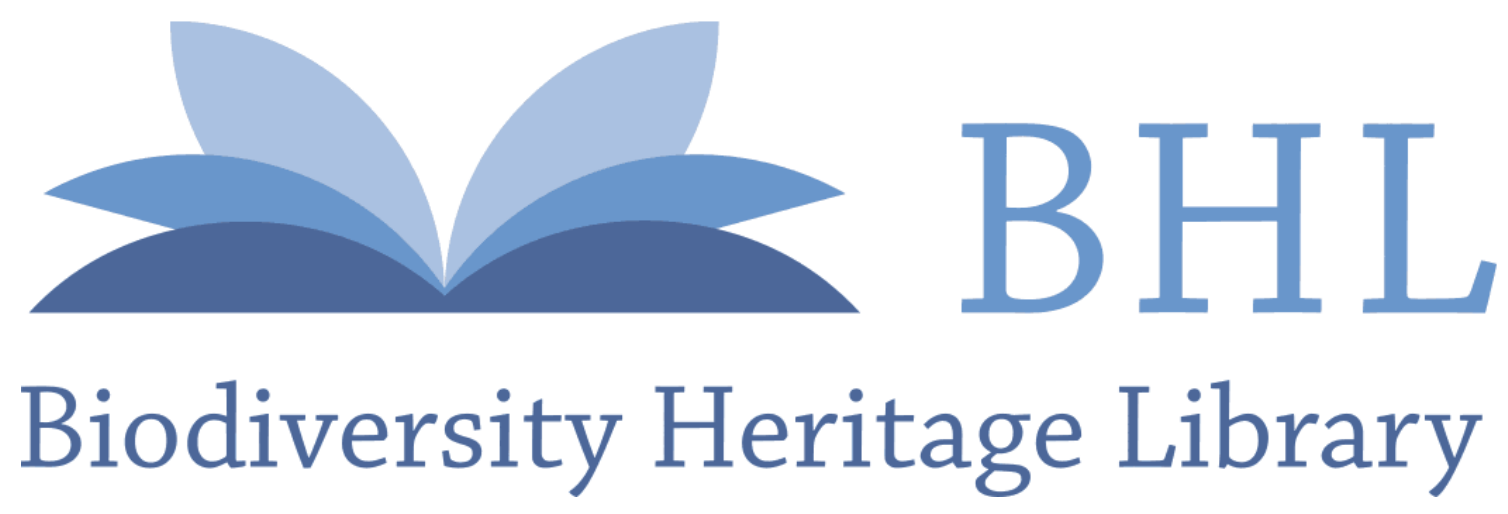

Whitney, David D. 1913. "AN EXPLANATION OF THE NON-PRODUCTION OF FERTILIZED EGGS BY ADULT MALE-PRODUCING FEMALES IN A SPECIES OF ASPLANCHNA." The Biological bulletin 25, 318-321.

https://doi.org/10.2307/1535960.

View This Item Online: $\underline{\text { https://www.biodiversitylibrary.org/item/17145 }}$

DOI: https://doi.org/10.2307/1535960

Permalink: https://www.biodiversitylibrary.org/partpdf/30958

\section{Holding Institution}

MBLWHOI Library

Sponsored by

MBLWHOI Library

\section{Copyright \& Reuse}

Copyright Status: NOT_IN_COPYRIGHT

This document was created from content at the Biodiversity Heritage Library, the world's largest open access digital library for biodiversity literature and archives. Visit BHL at https://www.biodiversitylibrary.org. 